\title{
Economic Rationality of Residents Living in the Area Prone to Merapi Volcanic Disaster
}

Komunitas: International Journal of Indonesian Society and Culture 9(2) (2017): 203-215

DOI:10.15294/komunitas.v9i2.10002 (C) 2017 Semarang State University, Indonesia p-ISSN 2086 - 5465 | e-ISSN 2460-7320 http://journal.unnes.ac.id/nju/index.php/komunitas

\section{Napsiah', Budhi Gunawan², Oekan S. Abdoellah³, Munandar Sulaeman ${ }^{3}$}

${ }^{1}$ Department of Sociology, Faculty of Social Sciences and Humanities, State Islamic University (UIN) Sunan Kalijaga Yogyakarta, Indonesia

${ }^{2}$ Graduate Program, Faculty of Social and Political Sciences, Padjadjaran University Bandung, Indonesia

${ }^{3}$ Sociology and Counseling Laboratory, Faculty of Animal Husbandry, Padjadjaran University Bandung, Indonesia

Received: June 2017; Accepted: July 2017; Published: September 2017

\begin{abstract}
The research concerned here was to know the economic rationality of residents who dwelled again in their former village after the eruption of Mount Merapi in 2010 and refused to be relocated by the government. A combined research method, namely, a combination between a qualitative method and a quantitative one, was used to uncover the rationality. The qualitative part of the research was conducted first by deciding informants considered knowledgeable about the matter under research. Then the informants were interviewed in turns decided via snowball sampling. Some secondary data were used to support the qualitative research. As for the quantitative part of the research, it was conducted afterwards by turning members of the households in the village into respondents. The finding of the research is as follows. The residents perceive the disaster not only as a dangerous natural phenomenon but also as an economic blessing because tourists' visits to the areas suffering from the impact of the disaster enable residents to have activities that have economic value. That economic rationality was what motivated them to return to their village though its condition is categorized by the government as unfit for dwelling.
\end{abstract}

\section{Keywords}

economic rationality; economic act; resident; Mount Merapi

\section{INTRODUCTION}

Government efforts to relocate residents living in disaster-prone areas frequently meet with refusal. The cause is difference in rationality between the government and residents in interpreting disaster (Lane 2003; Triyoga 2010; Laksono 1985; Dave 2008). For the government, disasters threaten the safety of residents so that residents living in danger areas should be moved. Meanwhile, residents regard a disaster as something which is indeed dangerous and should be avoided but when it has passed, they get various economic benefits so that the act of abandoning their village in the aftermath of Corresponding author

AdiSucipto Street No.1 Yogyakarta, Indonesia Email

napsiah@uin-suka.ac.id 
the disaster is not the main thing to do (Mei 2012; Usamah 2012; Riede 2014).

The difference in rationality in perceiving a disaster causes the government to make a one-sided decision in the matter of relocation so that frequently the relocation effort is refused by residents by returning to their village to live there again. In order that no one-sided decision occurs, the rationality of residents living in areas which are prone to volcanic disasters needs to be understood (Donovan 2010; Njome 2010; Warsini 2014; Simpson 2011).

Experts have already made efforts to understand the rationality of residents living in areas which are prone to volcanocaused disasters. At the international level, for instance, Lane (2003) studies the perception of residents in Banos concerning their vulnerability to hazards during the eruption of Mount Tungurahua in Ecuador. In Greece, Dominey and Minopoulos (2004) study the perception of the people living on two volcanoes in Santorini. Meanwhile, in South Iceland, simultaneous research by Johannesdottir and Gisladottir (2010) studies the perception of the Alftaver community living under the threat of the Katlan Volcano.

The studies on volcanic disasters at the international level above focus their attention on people's perspective concerning disaster perception and disaster mitigation. In the studies it is stated that residents living in areas which are prone to volcanic disasters obey the instruction from the government to leave their dwelling places during the occurrence of the disaster. However, after the disaster ends, they return to their places of origin because they consider that the disaster caused by the eruption of any mountain near them would be followed by a long peaceful period of time before it is repeated so that there is no reason for them to be away long from their homes (Torrence 2012; Torrence 2016; Sheets 2011; Chester 2010).

In relation with disaster linked to Mount Merapi in particular, there are previous studies using the perspective of sociology and conducted after a great eruption of Merapi but they are restricted to the theme of the strategy for survival after the Merapi eruption. For example, Wijayanti (2013) studies the change in people's occupation in result of the disaster caused by the eruption of Merapi in 2010 while Giyarsih (2012) studies how the relief supplies are made use of for survival in the temporary shelter called Shelter Gondang 3 in Cangkringan, Yogyakarta. Likewise, Sulastri (2012) study farmers' independence in the aftermath of the Merapi eruption in 2010 in the organic rice farm business in Klaten, Jawa Tengah, while Usman (2011) studies communities' survival strategy on the face of Merapi cooled lava.

Besides, a sociological study by Amiruddin and Widyanto (2011) on the strengthening of social solidarity after the Merapi eruption focuses on solidarity and the disaster tourism business run by residents of Cangkringan, Yogyakarta, while a study by Martief (2011) is on the empowerment of society on the face of the Merapi disaster. In addition, a study by Sukiman and Putra (2011) is on the participation of society members in the handling of the Merapi cooled lava. A study by Humaedi (2016) is on the social and cultural dilemma involved in relocating the living victims of the disaster caused by the eruption of Mount Rokatenda in Nusa Tenggara Timur.

Of all the research on the disaster phenomenon related to the eruption of Mount Merapi, none had previously studied in particular issues concerning the economic rationality of residents returning to live again in their villages after the occurrence of the disaster that had devastated their villages. Such research as that concerned here is important to conduct in order that disaster handling particularly concerning residents' relocation could be known after their rationality could be taken into consideration in the matter of relocation. According to $\mathrm{Ny}-$ gren (1999), if residents' rationality is not taken into consideration, it would have an impact in the form of failure in the relocation effort because residents do not respond well to it. In relation with it, it is necessary to make a study on understanding the rationality of residents who return to their villages at post-disaster time as what occurs in 
the village of Pangukrejo.

After the Merapi eruption in 2010, Pangukrejo has been one of the nine villages categorized as Disaster-Prone Area III by the government. Places for relocation considered safe for dwelling have been made available for residents of the nine villages. People of eight of the villages have been willing to accept the relocation but those of Pangukrejo have right from the very start been unwilling to be relocated. One by one the families concerned have rebuilt their homes and the area has become alive again as a village.

The research concerned here was to know the economic rationality of those residents in returning to their village, which has been devastated as a result of the Merapi eruption that has been classified as its greatest eruption so that the life resources of the residents have been severely damaged and the area concerned has been declared by the government as an area which is forbidden to be reinhabited.

\section{ACT OF ECONOMIC RATIONALITY}

In deciding what act to do, each individual is faced with various sorts of choices. The decision to determine a choice greatly depends on what would be attained with various kinds of considerations. According to Coleman (1994), the actor (in the sense of the doer of an act) would make a rational choice in accordance with the self-capacity or the resources possessed so that the advantages and disadvantages of the act to be done are already taken into account in the considerations.

The social act done for the sake of economic interest is a rational economic act (Weber 1978). Though economy is not the only reality dominating all aspects of life but it is part of the social system and it is deeply rooted in human activity and eventually dominates social life (Nugroho 2001). It all happens to any society, including the society that becomes disaster victims.

Though, according to Zack (2009), disasters cause the impact of the victims becoming the dependent on others because all resources of income-earning activity are gone, according to Rittichaiwat (2008) and Seaton (1996), some members of society who become disaster victims regard the disaster as one bringing not only danger but also economic blessing because such residents turn the damaged and destroyed places and even the places of mass graves into objects of tourism. By Petford et al. (2010), disaster tourism with such a condition is called dark tourism because such tourism occurs only when a disaster has occurred and prior to that the area concerned has not been a tourism area.

Something similar in tone is expressed by Ahimsa (2012) with the concept of disaster tourism. Though tourism is usually associated with having fun while a disaster brings damage and grief, the concept of disaster tourism becomes a relevant concept for an area that continuously receives visitors because of a disaster. The visits become an economic resource for the residents who are disaster victims.

The act of selling the post-disaster condition becomes a rational act (Shaw and Williams 2004) because it results in a source of income for residents living in areas that are prone to disaster, particularly that caused by a volcano. The income does not have the nature of being temporary because the recovery of a pre-disaster condition takes a long time. And throughout the same length of time residents make the post-disaster condition become a source of their income.

In relation with it, a disaster does not only bring about danger because after its ending, the condition left behind by the disaster becomes a source of income for the residents living around it. Thus, the economic rationality through the commodification (or the transformation into commodity) of disaster into an area of tourists' destination is the rationality of the residents returning to their villages though the area concerned is a disaster-prone one.

The research was conducted in Pangukrejo, one of the nine villages whose areas are categorized as Disaster-Prone Area III by the government after the 2010 Merapi eruption. Though the people of the other eight villages have been willing to be relocated, 
those of Pangukrejo have from the beginning refused being relocated. They live in their village again and have even made the area of their community become the central area of tourism in Merapi. In relation with that, the rationality of Pangukrejo residents has been dug up by using a combined research method, namely, a combination between a qualitative research method and a quantitative one (Cresswell 2009). The qualitative part of the research was conducted first at the community level to know how residents perceive or interpret the disaster while the quantitative part was conducted afterward at the household level to see the socioeconomic condition of those living in a disaster-prone area. The qualitative research was conducted by interviewing informants selected by means of a sampling method whose objective was to select those judged knowledgeable about, involved with, and mastering the information related to the research topic and problem (Patton 1990). Therefore, the informants in the research consisted of, first, parties officially concerned with community well being like village officials of various levels, second, informal figures like community figures and Pangukrejo residents, and, third, parties involved in the processes of economic activity like tour guides, vendors, and porters. The three informant groups were gathered through snowball sampling (Groenewald 2004). Besides interviews, observations were also conducted to reinforce the interview data. Secondary data from journals, previous research, and archives owned by the government agency formed to deal with disasters, namely, Badan Penanggulangan Kebencanaan ('the Disaster Mitigation Agency'), in the Province of Yogyakarta and the Regency of Sleman as well as those owned by the village of Pangukrejo itself were used to reinforce the primary data. After all the data were gathered, they were processed by being analyzed according to the model used by Huberman dan Mills (1994) through the stages of data reduction, data display, and drawing the conclusion.

After the qualitative research was done, the following step was to use the quantitative research by regarding as res- pondents the whole population consisting of family heads per household unit in Pangukrejo who had refused to be relocated and had returned to live in Pangukrejo again after the Merapi eruption in 2010. There were 96 family heads concerned becoming the respondents in the research. The whole population was taken as respondents (as in a census) because the population was relatively small and also, in order to get a picture of what the respondents thought, felt, and experienced that was not partial, it was to be directly obtained from them.

\section{Residents of the Pangukrejo Village and the Tourism Potential of Mount Merapi}

Pangukrejo is one of the villages lying on the southern slope of Mount Merapi, which is the most active volcano in the world with the eruption frequency of once every 3 to 5 years' time. In spite of that, prior to the eruption in 2010, Pangukrejo residents had kept living on that mountain slope for generations.

Before that eruption, Pangukrejo residents who were Muslims (Islam followers) making their living by farming and tending farm animals had long made themselves dependent on the resource potential of Mount Merapi. Besides, they also offered such service as providing lodgings for tourists visiting Merapi. In that way, Mount Merapi had been a resource for living to them not only when it was in an actively dormant state but also when it erupted because, among the eruption materials, there were sand and rocks, which became sources of income for residents living around them. In addition, the volcanic ash thrown out of Mount Merapi was a natural fertilizer that could make fertile the farmland of residents living around it.

\section{Post-Eruption Merapi Economic Activ- ity: "Volcano Tour Merapi" Tourism}

Before the Merapi eruption in 2010, Pangukrejo was one of the villages frequently receiving visits by tourists intending to enjoy the panorama of beauty and coolness of nature on the mountains. The tourists' visits had 
the nature of varying in length of time. There were some who made short visits but there were also others who made lengthy visits which could last for days and even weeks. During the visiting period, they surely needed the available places for spending the night in Pangukrejo. For that reason, Pangukrejo became one of the two villages that were never free from tourists' visits, the other being the village of Kinahrejo.

After the 2010 Merapi eruption, Pangukrejo has stayed being an area of tourists' visits. It has even become the main destination of tourists' visits. However, instead of coming to hire the services of tourists' lodgings, this time they come visiting to directly witness the condition of Pangukrejo, which is in a devastated state in result of the ferocity of the natural phenomenon in the form of the latest eruption of Mount Merapi, which has been categorized as the greatest in comparison with prior eruptions of the said volcano.

At the time the first visitors came after the eruption, Pangukrejo was seen as a mere expanse of sand and rocks. On the surface, the expanse was filled with large pieces of wood that had toppled and lay scattered in disorder. Thus, the area looked empty, dry, arid, and desolate. For a moment, it did not appear that the area had previously been where residents had lived because there were no signs of life. However, further south house buildings and roofs whose form was no longer in good order started to be seen. It was evidence that the expanse of sand and rocks had formerly been residents' preeruption place of habitation.

That identification became increasingly clearer when a stake marking the boundary of the village was found by a resident. But it was pitch black in color because it had been burned into a scorched state by the hot lava from Merapi. In addition, it was thickly covered with sand and volcanic ash. However, it was still intact and the writing on it could still be read. Thus, residents were sure that the discovery of the stake was proof that the area with the expanse of sand and the disordered condition of the objects atop it was their former housing area.
With Pangukrejo in such a ravaged condition, every day since then Pangukrejo had been visited by tourists. They came by using vehicles, which necessitated parking places while the environment on Merapi at that time was still filled with heat because of the eruption and smoke could still be seen to come from inside the ground so that the tourists could not directly bring their vehicles to the objects of their destination. Thus, parking places for cars and motorcycles became an important matter for the tourists.

In relation with it, residents opened parking places anywhere. There were some who intentionally opened parking places in their own property and there were also some who used for that purpose other people's places where there were no house buildings anymore. Even the areas along the roads were not rarely turned into parking places so that conditions in the stricken village were not neatly ordered because the whole area was crowded with visitors and vehicles parked everywhere. Other than offering parking places, residents also responded to the tourists' visits by turning into vendors and offering their services as tour guides.

The tour activities were coordinated into one organization of the type locally called paguyuban, something like community in the sense of people with the same interest. The purpose of the formation of the paguyuban, which was then called Paguyuban Volcano Tour Merapi ('the Community of the Merapi Volcano Tour'), was not only to put their environment in order to make it become an area which was a tourists' destination but also to show the residents' togetherness in rising from the disaster conditions by reviving the economic condition in their village, which had been devastated by the Merapi eruption in 2010. Through the togetherness they did some disaster commodification by selling disaster areas as objects of the Merapi exploration tour.

\section{Objects and Transport Means of the Merapi Exploration Tour}

Then the Pangukrejo residents made increasingly more intense efforts to turn their 
area into an area of tourists' visits. They not only formed a paguyuban to contain in one organization all the residents' activities in the tourism sector but also endeavored to weave collaboration with various parties among other village residents directly and indirectly feeling the harmful impact of the disaster as well as with formal institutions. The purpose of the collaboration was to widen the area of the tourism objects so that, instead of being limited to their own village, it included other villages in the Merapi environment as well. In view of the matter that the appeal of the tourism activity was from the condition resulting from the Merapi disaster, they considered it necessary that the other villages also became part of the tourism objects.

The first collaboration that they offered to weave was with Kinahrejo residents, with the consideration that Kinahrejo was a phenomenal village which had been well known to the general public long before the occurrence of the Merapi eruption in 2010. In the event of the 2010 Merapi eruption, Kinahrejo not only experienced a severe degree of destruction but also served as part of the life story of Mbah Maridjan, a local famous figure who died tragically because of hot lava there. The severe damage and also some objects serving as legacy from the said local figure in the form of a house and a mosque were turned into objects of the Merapi exploration tour.

The collaboration offered to residents of Kinahrejo was positively responded to. They accepted the offer of collaboration from the Pangukrejo residents though, at that time, they had left their village to undergo relocation in Karang Kendal, another village which was $3 \mathrm{~km}$ far from Kinahrejo. The collaboration became a means for them to return to their village, though only for a short time.

In addition, the Pangukrejo residents also weaved collaboration with residents of four other villages (namely, Petung, Kalitengah Lor, Kalitengah Kidul, and Srunen), all of whom were already in a relocation area at that time, by first asking for their willingness to let their old villages be turned into objects of tourists' destination. It got positive responses because all those residents were willing in their respective ways to give Pangukrejo residents a chance to develop their already vacant villages into areas of tourists' destinations.

The meeting between the Pangukrejo residents and the other village residents who were victims of the Merapi eruption,

Table 1. Objects and Means of Transport of the Merapi Volcano Tour

\begin{tabular}{|c|c|c|c|c|c|c|}
\hline \multirow{2}{*}{ No. } & \multirow{2}{*}{ Tour Object } & \multirow{2}{*}{$\begin{array}{l}\text { Means of } \\
\text { Transport }\end{array}$} & \multicolumn{3}{|c|}{ Duration } & \multirow{2}{*}{ Price } \\
\hline & & & Short & Medium & Long & \\
\hline 1 & $\begin{array}{l}\text { River Opak, Petung Village, Mini } \\
\text { Museum, Bunker, Alien Rock, Mass } \\
\text { Grave, Bol Dune }\end{array}$ & & $\begin{array}{c}1.5 \\
\text { hours }\end{array}$ & & & 250.000 \\
\hline 2 & River Opak, Mini Museum, Bunker, & & & & & \\
\hline & $\begin{array}{l}\text { Kaliadem Sands, Alien Rock, Mbah } \\
\text { Maridjan's Grave, River Gendol, } \\
\text { Mass Grave, Bol Dune }\end{array}$ & Car & & $\begin{array}{c}2.5 \\
\text { hours }\end{array}$ & & 350.000 \\
\hline 3 & $\begin{array}{l}\text { Mini Museum, Permanent Refugee } \\
\text { Housing, Mbah Maridjan's Grave, } \\
\text { Glagahsari Hill, Alien Rock, Bunker, } \\
\text { Kaliadem Sands, Mass Grave, Bol } \\
\text { Dune }\end{array}$ & & & & $\begin{array}{c}3 \cdot 5 \\
\text { hours }\end{array}$ & 450.000 \\
\hline $\begin{array}{l}4 \\
5\end{array}$ & $\begin{array}{l}\text { Home of the late Mbah Maridjan } \\
\text { Petung Hill, Kaliadem Sands }\end{array}$ & & 1 hour & 2 hours & & $\begin{array}{r}50.000 \\
150.000\end{array}$ \\
\hline 6 & Petung Hill, Glagahsari Hill & 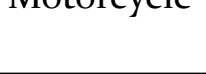 & & & $\begin{array}{c}3 \\
\text { hours }\end{array}$ & 250.000 \\
\hline
\end{tabular}

Source: Secondary Data, 2015. 
together with some village officials, resulted in an agreement to make certain locations become objects of Merapi exploration tours. In addition, the villages in the environment of Merapi which had been buried by Merapi matter and the rivers in the environment of Merapi whose surface had become level with that of residents' farmland were to become part of the objects of the Merapi exploration tours but they were not to be specifically mentioned as such objects because these areas were to serve as sights to be seen on the way to other objects.

After determining the objects that were to be the destinations in the Merapi Exploration Tour, Pangukrejo residents at once coordinated the means of tourist transport to be used, namely, car rental and motorcycle rental, to reach the objects of the tour. The objects to be reached by motorcycle were on higher grounds while those to be reached by car were on lower flat lands. In addition, residents also set the price for each tourists' visit (Table 1 ).

It is the case with areas of tourists' destinations in general that in the tour arena there are people selling food and drinks as well as those selling souvenirs. So was the case of the Merapi tourism area, warung being the sector to count on the most there (with warung referring to small shop or food stall business). Residents in that area opened as widely as possible the opportunity for anyone interested to participate in the warung sector. They used the most direct way, called gethok tular in Javanese, namely, by word of mouth, to spread the information of the opportunity. Apparently, that effort of theirs received positive response from various parties because in a short time one by one people originating in Magelang, Pakem, and Turi contacted the head of the paguyuban for the warung business to rent a kiosk, a small building for business open on at least one side, in the arena of the Merapi exploration tour.

That situation has remained relatively the same. The owners of kiosks themselves are not always merchants because not all Pangukrejo residents sell things for a living; often they just offered their kiosks for rent by non-natives. As for the renting system, the kiosks are rented per week, per month, or per year. Though differing in the system used, there is something which is the same in the matter of the payment of the rent, namely, it is done at the beginning with a price according to the agreement between both parties. The warungs that are in the arena of the disaster tour sell food and drinks. However, there are also warungs that sell souvenirs.

\section{Residents Involvement}

Of the 96 households of the Pangukrejo residents, 38 (39.6\%) have members with business in the tourism sector with a system of personal or self-management. They are distributed into the car rental sector, the motorcycle rental sector, and the warung sector. The ticketing and parking sectors are managed by groups. In that way, somehow all the 96 households of Pangukrejo residents are involved in the management of the tourism sector.

\section{Self-Managed Tourism Economic Ac- tivities by Pangukrejo Residents}

The businesses self-managed by residents in the course of developing disaster tourism are as follows.

\section{1) Sector of Car Rental}

Under the administration of Paguyuban Volcano Tour Merapi, there are 4 paguyubans (or communities) of tour cars in operation, respectively calling themselves Paguyuban Hardtop, Paguyuban Adventure, Paguyuban Jeep, and Paguyuban Community 46. Each of those car paguyubans operates with its own armada in the arena of the Merapi exploration tour. Each day, there are 38 cars from the 4 paguyubans operating in the Merapi exploration tour. Of that number, 8 cars belonging to Pangukrejo residents are distributed into the 4 car paguyubans while the 30 other cars belong to Kinahrejo and Srunen residents, who are also living victims of the Merapi eruption in 2010.

As for the number of Pangukrejo residents involved in the renting of the jeep type of cars, they comprise $8.3 \%$ of the 39.6 
$\%$ of Pangukrejo residents self-managing the tours. They are distributed into the four car paguyubans, with $2.1 \%$ of them in the Hardtop Armada, $3.1 \%$ of them in the Jeep Armada, $2.1 \%$ of them in the Armada of Community 86 , and $1.0 \%$ of them in the Adventure Armada.

Any of the tour-running people involved in the car rental sector, whether the person is a Pangukrejo resident or a Kinahrejo resident, is given a chance to have only one car to operate in the tour arena. This restriction is intended to give an equal chance to other residents who are also living victims of the Merapi eruption to enter this sector because in practice the work in the sector of car rental involves parts of the surrounding environment turned into tour objects. Besides, hopefully there is no business monopoly for certain parties because the business is intended to be evenly shared in order that such aforesaid victims could continue to survive in the post-eruption Merapi environment before their old occupations could be relied on again.

\section{2) Sector of Motorcycle Rental}

Prior to the Merapi eruption in 2010, there was a motorcycle in each household in Pangukrejo. The motorcycle was used daily as means of personal transport and also as means of economic activities like carrying grass piles and selling products provided by cows. Other than that, $4(4.2 \%)$ of the 96 households made the motorcycle function as means of such economic activities as being leased for motorcycle taxi business in the environment of Mount Merapi or the Pangukrejo residents operated it themselves in a tour of the environment of Mount Merapi.

After the Merapi eruption in 2010, a motorcycle is an extremely important means of transport for those residents. At the beginning, the money received from the government as compensation for the cattle that they lost to the eruption was allocated by a few warga for the purchase of a motorcycle. The motorcycle was not only used as means of personal transport but also turned into a means of something economically productive like escorting a tourist to places inaccessible by car.

Right then and there they became motorcycle taxi riders and simultaneously tour guides for anyone wanting to visit areas suffering from the eruption impact. But they had difficulty when escorting tourists to places accessed via steeply ascending roads because often the motorcycle being used was unable to be ridden up such roads. In relation with it, they considered it necessary to have a trail motorcycle, which could be ridden to high places. Therefore, one by one they replaced their motorcycles with trail motorcycles and joined the motorcycle paguyuban.

Under the auspices of Paguyuban Volcano Tour Merapi there are now 54 motorcycles in operation in the tour arena. Of that number, up to $18.8 \%$ are of $39.6 \%$ of the Pangukrejo residents involved in the sector of motorcycle rental. Each Pangukrejo resident has a motorcycle so that, of the 54 motorcycles in the tour arena, 18 belong to Pangukrejo residents while the 36 others belong to Kinahrejo residents.

Though each resident is given a chance to have two motorcycles, each Pangukrejo resident has one motorcycle only in the tour arena because they consider that the available motorcycles that are 54 in number already suffice for being operated in the tour arena. Because the distance covered is relatively short and the road travel is not overly long in duration, ranging from 60 minutes to 3 hours, the available number of motorcycles are already adequate for serving tourists even when tourists' visits are high in frequency.

\section{3) Sector of Warung}

After the 2010 Merapi eruption, initially 12.5 $\%$ of Pangukrejo residents became peddlers in the tour environment, going around selling their wares there. They only sold bottled mineral water obtained from shopkeepers close to their village. The shopkeepers were willing to give several kinds of their merchandice to Pangukrejo residents to sell without having to pay at once in cash. In addition, they also helped by willing to bring the merchandice to the Pangukrejo re- 
sidents who would like the merchandice to be delivered to them.

In relation with the certainty of obtaining merchandice easily, these Pangukrejo residents then had the initiative to build warungs on the sides of the roads to the arena of the Merapi. Up to $10.4 \%$ of these peddlers built warungs on the road sides. They set up small buildings made of bamboo and plastic tarpaulin roofs with the sides allowed to be without walls to serve as the warungs. The warungs are made to be sufficiently far from each other. According to them, it is to lessen the feeling of competition among them. There is something the same in the types of merchandice in the warungs, namely, they all sell drinks and some snacks. Meanwhile, some $2.1 \%$ of them still continued working as peddlers in areas with many visitors.

Now, besides the tour activities that were self-managed by individuals, there are also those managed together by groups, namely, the activities in the ticket sector and the parking sector. The ticket sector and the parking sector under the authority of Paguyuban Volcano Tour Merapi are managed by groups involving all Pangukrejo residents. There is a system that regulates the division of the earning. According to that system, $60 \%$ of it is for those on duty on the same day and the remaining $40 \%$ is for the village treasury via the head of Paguyuban Volcano Tour Merapi. The $60 \%$ is then divided evenly among the 10 residents on duty that day. The income that they receive for one day greatly depends on the number of tourists' visits on that day.

\section{Group-Managed Tourism Economic Activities}

As previously mentioned, the ticket sector and the parking sector under the wings of Paguyuban Volcano Tour Merapi are managed by groups involving all Pangukrejo residents, who come from 96 families. They are on duty in groups with ten of them working in each sector for one day. Thus, members of each household could have a share in the management of the two sectors by taking turns going on duty there.
As aforesaid, it is in these two sectors that, at the end of one day's work, what is earned that day is first divided into 6o \% of it for those on duty that day and the remaining $40 \%$ to be deposited in the village treasury by the head of Paguyuban Volcano Tour Merapi, with the $60 \%$ being then evenly distributed to the 10 people on duty that day. Thus, as said before, the income they receive each day depends very much on the number of tourists' visits that day.

\section{Income Certainty}

The involvement of residents in the sector of the Merapi exploration tour exerts a great influence on their income because there is a certainty in their daily income. Up to $100 \%$ of them say that after being involved in the sector of the Merapi exploration tour, they are sure to earn an income per month.

The income of residents involved in the economic activity of the Merapi exploration tour is on the average as follows. Each resident involved in the sector of car rental earns an average net income of $\mathrm{Rp}$ 3,000,00o-- up to Rp 6,00o,00o.- per month. Each resident involved in the sector of motorcycle rental earns an average income of $\mathrm{Rp}$ 1,00o,00o.- up to Rp. 2,00o,00o.- per month. Each resident involved in the sector of running a warung earns an average income of $\mathrm{Rp}$ 1,00o,ooo.- up to Rp 1,500,000.- per month. Somewhat unlike them, each resident involved in the sector of ticket attaching plus withdrawal and the ticket teller sector earns an average income of Rp 9o,ooo.- up to Rp 300,000.- per month.

In relation with it, the tourism economic activity has become residents' fixed or permanent source of income after their return to their village. In fact, up to $75 \%$ of residents say that the tourism economic activity could serve as the source of the capital needed to finance the rebuilding of their old businesses such as tending cows and the rebuilding of the tourists' cottage business which has become totally paralyzed because of that eruption of Mount Merapi occurring in 2010. 


\section{Behind Pangukrejo Residents Return to Their Village}

Disasters cause damage and loss and even loss of lives, which in the end cause the survivor to lead a long life as a dependent because the basis of the economy is gone (Zack 2009; Mei \& Lavigne 2012; Simpson et al. 2011; Usamah \& Haynes 2012; Warsini et al. 2014). In consequence of that condition, residents are assumed to have no sufficient confidence to rise from the disaster effects. Such an assumption becomes rational in view of the matter that not all of the survivors of a disaster have sufficient endurance or resilience on the face of the post-disaster condition so that to these surviving disaster victims various negative impacts come in result of the disaster.

Unlike the opinion expressed by Zack (2009), for Pangukrejo residents, the Merapi eruption has not only meant a disaster because in the aftermath of the disaster they have obtained various economic benefits from it. The ability of managing the disaster in ways that have made it have economic potential has resulted in great living resources for those in the post-eruption Merapi region. By means of that ability, residents have not had to depend their living for long on parties from outside. Their ability in the disaster management has even opened new job opportunities for themselves and for other residents around the Merapi slopes.

Activities of tourism in the middle of the occurrence of a disaster becomes a matter of interest because tourism is usually associated with fun and pleasure and with one's journey to pleasant sites. However, the appearance of the term disaster is in this case controversial because a disaster is a condition which is terrifying and heartrending. That conceptual controversy between tourism and disaster has no strong argument in view of the matter that the tourist journey is not restricted to pleasant matters but also includes painful conditions (Rittichaiwat 2008; Seaton 1996; Ahimsa 2012; Riede 2014). In fact, Petford (2010) regard disaster tourism as dark tourism because the area being visited has not been previously intentionally opened for tourists' visits and it has been the occurrence of a disaster that has attracted tourists and turned the site into an area of tourists' visits.

Disaster tourism or dark tourism has also occurred in the Pangukrejo area. After the latest Merapi eruption, tourists' visits to the disaster area have continuously occurred day after day. It has indirectly created tourism objects from the areas suffering from the impacts of the disaster. The decision of regarding the situation as a chance to develop their area into one for tourism has been a form of collective response from Pangukrejo residents, resulting in the formation of Paguyuban Volcano Tour Merapi to manage the tour arena that they call "Explore Merapi".

The tour activity called "Explore Merapi" is an effort of Pangukrejo residents to sell the post-disaster conditions like the areas directly subject to the impact of the disaster, residents' homes hit by the eruption, village areas buried in sand material, mass graves, and the grave of a local famed figure. They have managed to turn those spots into objects for tourism.

That act of Pangukrejo residents' is, according to Shaw and Williams (2004), is an act of disaster commodification, namely, an act of selling a condition that has a high selling power. The selling of a condition is not restricted to only a good and pleasing condition because it is also possible to sell a condition that is hurtful and heartbreaking like a post-disaster condition.

The ferocity of a natural phenomenon in the form of the eruption of Mount Merapi, which has caused damage, destruction, and even the death of inhabitants around it has seemed to possess a high selling power in view of the continuous daily arrivals of tourists. That has been why the residents have responded by selling the post-disaster condition, which has then become an activity with an economic value. Moreover, such selling needs no modifications of the disaster traces because the tourists that come intend to witness directly the objects in the condition of devastation in their natural state. According to Ahimsa (2012), if the natural condition is modified, it has the potential of 
not attracting tourists' interest because such disaster modification means altering the natural condition resulting from the disaster. Something has been accordingly done by Pangukrejo residents by not making any repairs in the areas that become the objects of the tourists' interest and by arranging things in some ways in certain arenas only so that the tourists' visits become more orderly.

This research finding is in line with that of Rittichaiwat (2008) in studying what is called the post-tsunami thanatourism in Thailand. Residents sell areas, sites, and a local famed figure's grave naturally as postdisaster objects to be viewed by tourists. Such places become objects that attract tourists as indicated by the high degtree of tourists' visits each month. However, this finding is in one aspect not quite in line with the result of research by Lane (2003) on Mount Tungurahua, Ecuador, that, after its eruption, the area of Banos residents has become a tourism area by means of their selling of objects, places, and also the homes of local inhabitants as objects of tourism so that the area has become an area of disaster tourism but the enterprise has been managed by the government to revive the economic activity of inhabitants after the eruption of Mount Tungurahua which has caused severe damages and great losses. The act of disaster commodification (or of selling the disaster-caused condition) done by Pangukrejo residents has had positive impacts on the job opportunities for local inhabitants. This is in line with Spillane (1994), who states that the tourism sector could absorb the workforce because the tourism sector could develop when there are support sectors within it. Therefore, the advantage of having the tourism sector here is that it is capable of absorbing the local workforce. The same thing is expressed by Miller and Morisson (1985) in saying that the appearance of a tourism area could open job opportunities for the people.

The act of Pangukrejo residents done by means of disaster commodification becomes something of interest because residents could thus open new fields of work. That is what then differs their case with ot- her cases of surviving disaster victims. Sometimes the disaster victims could quickly get back on their feet because they have social capital but their ability to open new work fields does not materialize. That is revealed in research by Surjono (2010) in the case of the disaster of the earthquake in Bantul. Another case indicates that residents who are living victims of a disaster are able to recruit the workforce into sectors of disaster tourism but the initiative of turning the area into a tourism area, nstead of coming from the residents, comes from the government, as previously mentioned in relation with the research by Lane (2003) after an eruption of Mount Tunggurahua in Ecuador.

The tourism economic activity of "Explore Merapi" has become a new source of income for Pangukrejo residents after the Merapi eruption in 2010. The tour activity has even become the sector most relied on. In relation with it, residents have depended their living on the sector of disaster tourism. Though they are aware that this sector would not forever support their life, the disaster tourism activity at least becomes one alternative activity that earns them an income. It is in line with Petford et al. (2010), who state that when disaster tourism is conducted at the time the disaster has just occurred, tourist visits in response to it would intensify each day. However, along with the regaining of a condition free from signs of any impact of disaster, the tourist visits would decrease in intensity and there would even be no more tourists' visits. Thus, the disaster tourism becomes a temporary alternative economic source for residents who are living victims of the disaster.

The act made by Pangukrejo residents by means of their empowerment of the potential of Mount Merapi is their effort as people of that mountain to meet their living needs. The ways they use are very potentially different from those used by those who are not mountain people. It is in line with an opinion expressed by Weber (1978) in saying that a social act that could be considered rational by the party who does it could be considered irrational by other parties. Disaster-based economic activity becomes 
rational for disaster victims left alive after the disaster because it becomes an alternative economic activity as strategy to continue their survival. Nevertheless, for outside parties, the disaster-based activity is potentially irrational because the devastated environment in result of a disaster is not potential in any economic way; instead, it has the potential for becoming a new disaster because there are various possibilities for a disaster to happen in result of not being ready to manage the environment that has changed in a short time.

In the present context, whether an act is rational or irrational depends very much on who interprets the act. With reference to Weber (1978), who says that a rational social act is an act done with a certain motive, the act done by Pangukrejo residents in managing the post-eruption environment of Mount Merapi is an economic act. Coleman (1994) says that an economic act has the nature of being practical because its purpose is to meet economic needs. That opinion of Coleman's comes to be in line with the said act done by Pangukrejo residents.

\section{CONCLUSION}

The disaster handling effort planned by the government in relation with the disaster in the form of the terrible eruption of Mount Merapi in 2010, in the matter of relocation in particular, received a refusal from a certain group of residents who, prior to the occurrence of the disaster, had long lived in the areas around Mount Merapi. The reason behind the refusal is related to these residents'rationality, which differs from the government's. For these residents, in their own subjective perspective, a disaster is indeed something dangerous but the effort to abandon the dwelling place categorized by the government as a disaster-prone area is not the main thing that should be done. The research concerned here concludes that whatever the condition of the village is and though it has been categorized by the regional government authorities as an area unfit for dwelling, the area possesses economic potential that could be turned into a source of residents living. That is the economic rationality that has motivated the residents to return to their place of origin.

\section{REFERENCES}

Ahimsa, H.S.P., 2012. Etno Bencana: Etnosains untuk Kajian Bencana in Respon Masyarakat Lokal atas Bencana. Mizan, Bandung.

Amiruddin, M. and Widhyharto, S., 2010. Komersialisasi Bencana: Transformasi Sosial Masyarakat Pasca Bencana Erupsi Merapi Melalui Vulcanology Tour Di Cangkringan”. Sosiologi Reflektif, 12 (6), pp.57-70.

Chester, D.K., \& Duncan, A.M., 2010. Responding to disasters within the Christian tradition, with reference to volcanic eruptions and earthquakes. Religion, 40(2), pp.85-95.

Coleman, J.S., 1994. A Rational Choice Perspective on Economic Sociology. pp.166-18o. in Smelser, N.J. and Richard, S. (Ed). The Handbook of Economic Sociology.

Cresswel, J.W., 2009. Research Design: Qualitative, Quantitative, and Mixed Methods and Approaches. Sage Publications, California.

Dominey, H.D., and Minopoulos, M., 2004. "Perception of Hazard and Risk on Santorini". Journal of Volcanology and Geothermal Research, 137, pp.285-310.

Donovan, K., 2010. Doing social volcanology: exploring volcanic culture in Indonesia. Area, 42(1), pp.117-126.

Dove, M.R., 2008. Perception of Volcanic Eruption as Agent of Change on Merapi Volcano, Central Java. Journal of Volcanology and Geothermal Researc, 172, pp.329-337.

Giyarsih, S.R., 2012. Strategi Penghidupan Korban Bencana Merapi di Hunian Sementara in Merapi dalam Kajian Multidisipliner. Sekolah Pascasarjana UGM, Yogyakarta.

Granoveter, M., 1985. Economic Action and Social Structure: The Problem of Embeddedness in American Journal of Sociology, 91 (3), pp.481510.

Groenewald, T., 2004. A Phenomenological Research Design Illustrated. International Jurnal of Qualitative Methods, 3 (10), pp.1-26.

Huberman, M.A. and M.M. Miles. 1984. Data Management and Analysis Methods in Denzin, K.N. and Loncoln, Y.S. (Ed). Handbook of Qualitative Research. Sage Publication, London.

Humaedi, M.A., 2016. Relocation Dilemma: Social and Cultural Challenges in the Relocation of the Victims of the Mount Rokantenda Disaster. Komunitas International Journal of Indonesian Society and Culture, 8 (2), pp.221-235.

Johannesdottir and G. Gisladottir. 2010. People Living Under Threat of Hazard in Southern Iceland: Vulnerability and Risk Perception. Naturaal Hazards and Earth System Sciences, 10, pp.407- 420. 
Laksono, M.P., 1985. Persepsi Setempat dan Nasional Mengenai Bencana Alam: Sebuah Desa di Gunung Merapi in Peranan Kebudayaan Tradisional Indonesia dalam Modernisasi. Yayasan Obor Indonesia, Yogyakarta.

Lane, L.R., 2003. Hazard Vulnerability in Socio-Economic Context: An Example from Ecuador. Dissertation. University of South Florida.

Martief, M.L., R. Marpaung, Suriadi, A., 2011. Pemberdayaan Masyarakat Dalam Menghadapi Bencana Merapi in the Proceedings of the Workshop on Mitigasi Bencana Lahar Gunung Merapi Pascaerupsi 2010. Balai Sabo, Pusat Penelitian dan Pengembangan Sumber Daya Air, Yogyakarta.

Mei, E.T.W., \& Lavigne, F., 2012. Influence of the institutional and socio-economic context for responding to disasters: case study of the 1994 and 2006 eruptions of the Merapi Volcano, Indonesia. Geological Society, London, Special Publications, 361(1), pp.171-186.

Miller, R.C. and A.M. Morrison. 19985. The Tourism System: An Introductory Text. Englewood Cliffs, New Jersey, Prentice Hall.

Njome, M.S., Suh, C.E., Chuyong, G., \& de Wit, M.J., 2010. Volcanic risk perception in rural communities along the slopes of mount Cameroon, West-Central Africa. Journal of African Earth Sciences, 58(4), pp.6o8-622.

Nugroho, H., 2001. Uang Rentenir dan Hutang Piutang di Jawa. Pustaka Pelajar, Yogyakarta.

Nygren, A., 1999. Local Knowledge in the Environment-Development Discourse from Dichotomies to Situated Knowledges. Journal of Critique Anthropology 19 (3), pp.269-288.

Patton, M.Q., 2009. Metode Evaluasi Kualitatif. Translation by Budi Puspo Priyadi. Pustaka Pelajar, Yogyakarta.

Petford, N.J., Fletcher, Y., and Morakabati. 2010. "On the Economics and Social Typology of Volcano Tourism with Special Reference to Montserrat, West Indies" in Cooper, P.E. and Cooper, M. (Eds.) Volcano and Geothermal Tourism: Sustainable Geo-Resources for Leisure and Recreation. Earthscan, Washinton, DC.

Riede, F., 2014. Towards a science of past disasters. Natural hazards, 71(1), pp.335-362.

Rittichaiwat, N.B., 2008. Responding to Disaster: Thai and Scandinavian Tourist Motivation to Visit Phuket, Thailand. Journal of Travel Research.

Seaton, A.V., 1996. Guided by the Dark: from Thanatopsis to Thanatourism. International Journal of Heritage Studies, 2, pp.234-244.

Shaw, G. and Williams, A., 2004. Tourism and Tourism Space. Sage Publication, London.

Sheets, P., 2011. Pilgrimages and persistent social memory in spite of volcanic disasters in the
Arenal area, Costa Rica. Ancient Mesoamerica, 22(2), pp.425-435.

Simpson, A., Johnson, R.W., \& Cummins, P., 2011. Volcanic threat in developing countries of the Asia-Pacific region: probabilistic hazard assessment, population risks, and information gaps. Natural Hazards, 57(2), pp.151-165.

Sukiman and Putra, S.S., 2011. Peran Masyarakat dalam Penanggulangan Lahar Dingin Gunung Merapi in the Proceedings of the Workshop on Mitigasi Bencana Lahar Gunung Merapi Pascaerupsi 2010. Balai Sabo, Pusat Penelitian dan Pengembangan Sumber Daya Air, Yogyakarta.

Sulastri, E.S., \& Hariadi, S.S., 2012. Kemandirian Petani dalam Usaha Tani Padi Organik Pasca Erupsi Merapi in Merapi dalam Kajian Multidisplin. Sekolah Pasca UGM, Yogyakarta.

Surjono, G., 2007. Peranan Modal Sosial dalam Rekonstruksi Korban Gempa Bumi. Citra Media Press, Yogyakarta.

Torrence, R., 2012. Volcanic disasters and agricultural intensification: A case study from the Willaumez Peninsula, Papua New Guinea. Quaternary international, 249, pp.151-161.

Torrence, R., 2016. Social resilience and long-term adaptation to volcanic disasters: The archaeology of continuity and innovation in the Willaumez Peninsula, Papua New Guinea. Quaternary International, 394, pp.6-16.

Triyogo, L.S., 2010. Merapi dan Orang Jawa: Persepsi dan Kepercayaan. Grasindo, Jakarta.

Usamah, M., \& Haynes, K., 2012. An examination of the resettlement program at Mayon Volcano: what can we learn for sustainable volcanic risk reduction?. Bulletin of volcanology, 74(4), pp.839-859.

Usman, S., 2011. Adaptasi Masyarakat terhadap Lahar Dingin Merapi in the Proceedings of the Workshop on Mitigasi Bencana Lahar Gunung Merapi Pascaerupsi 2010. Balai Sabo, Pusat Penelitian dan Pengembangan Sumber Daya Air, Yogyakarta.

Warsini, S., Mills, J., \& Usher, K., 2014. Solastalgia: living with the environmental damage caused by natural disasters. Prehospital and disaster medicine, 29(1), pp.87-90.

Weber, M., 1978. Economy and Society: An Outline of Interpretive Sociology. University of California Press, Berkeley and Los Angeles, California.

Wijayanti, W.R.A., 2013. Perubahan Pekerjaan Masyarakat Sebagai Akibat Dari Bencana: Studi Kasus Kawasan Wisata Volcano Tour Gunung Merapi, Sleman. Perencanaan Wilayah dan Kota, 24(1), pp.19-34.

Zack, N., 2009. Ethic for Disasters. Rowman \& Littlefield Publisher, Plymouth, UK. 